\title{
ПРИБУТКОВІСТЬ ТУРИСТИЧНОЇ ГАЛУЗІ ЯК ФАКТОР СОЦАЛЬНО- ЕКОНОМІЧНОГО РОЗВИТКУ ПОСТКОНФЛІКТНОЇ ТЕРИТОРІЇ
}

DOI: $10.32620 /$ cher.2020.2.02

Постановка проблеми: Всесвітня пандемія, викликана COVID-19 призвела до світової кризи туристичної галузі, але, водночас, створила умови для розвитку внутрішнього туризму в Україні. Особливо, на цей шанс потребують постконфліктні території Донбасу, де карантин поглибив депресивну соціально-економічну ситуацію. Постає питання пошуку заходів щодо відновлення прибутковості суб'єктів туристичної сфери даного регіону. Мета дослідження: визначити напрями підвищення прибутковості туристичної галузі постконфліктних територій сходу України з урахуванням сучасних особливостей їх соціально-економічного розвитку. Предмет дослідження: теоретичні та практичні аспекти підвищення прибутковості туристичних підприємств Луганської і Донецької областей для відновлення роботи регіональної туристичної галузі та отримання мультиплікативного ефекту і розвитку соціально-економічної системи регіону. Методи, використані в дослідженні: системний підхід, структурно-логічний і статистичний аналіз, синтез, узагальнення. Гіпотеза дослідження: передбачає використання підходу, за яким туристичні підприємства постконфліктної території сходу країни мають системно переглянути та змінити застарілі шаблони роботи для подолання точки беззбитковості та загальної системної кризи після тривалого карантину. Виклад основного матеріалу. За результатами проведеного аналізу визначено, що для туристичних підприємств Луганщини і Донеччини особливо актуальні: подолання негативного впливу зовнішніх факторів, створення інноваційного продукту та диверсифікація діяльності, інтеграція в інші галузі. Основними способами, що найкраще допоможуть досягненню необхідного рівня прибутковості, є діджиталізація та впровадження сучасних методів управління персоналом, комплексні заходи маркетингової та рекламної діяльності, а також обов'язковий аналіз отриманих фінансово-економічних показників діяльності. Оригінальність та практична значимість дослідження: представлені результати та запропоновані рекомендації грунтуються на комплексному порівняльному аналізі поточної ситуації туристичної галузі на регіональному рівні, викладені пропозиції представляють інтерес для практиків і актуальні для впровадження у більшості туристичних організацій Донбасу. Висновки. Головні вимоги успішності реалізації запропонованих напрямів - позбавлення від застарілих шаблонів, обгрунтованість та системність у всіх процесах і на всіх етапах роботи.

\section{Ключові слова:}

туристичне підприємство, прибутковість, ефективність господарської діяльності, посткнофліктна територія, соціально-економічний розвиток.

\section{PROFITABILITY OF THE TOURIST INDUSTRY AS A FACTOR OF SOCIO-ECONOMIC DEVELOPMENT OF THE POST-CONFLICT TERRITORY}

Formulation of the problem. The global pandemic caused by COVID-19 led to a global crisis in the tourism industry, but at the same time created conditions for the development of domestic tourism in Ukraine. The post-conflict territories of Donbass, where quarantine has deepened the depressed socioeconomic situation, especially need this chance. There is a question of finding measures to restore the profitability of tourism entities in the region. The aim of the research: to determine ways to increase the profita-

1 Зеленко Олена Олександрівна, д-р екон. наук, професор кафедри «Міжнародна економіка і туризм», Східноукраїнський національний університет імені Володимира Даля, м. Сєвєродонецьк, Україна.

Zelenko Olena, Doctor of Economic Science, Professor of International Economics and Tourism Department, Volodymyr Dahl East Ukrainian National University, Severodonetsk, Ukraine.

ORCID ID: 0000-0003-4880-246X

e-mail: zelenko.olena@gmail.com

2 Денищенко Людмила Вікторівна, старший викладач кафедри «Міжнародна економіка і туризм», Східноукраїнський національний університет імені Володимира Даля, м. Сєвєродонецьк, Україна.

Denishchenko Lyudmila, senior officer of International Economics and Tourism Department, Volodymyr Dahl East Ukrainian National University, Severodonetsk, Ukraine.

e-mail: d_lu@ukr.net 
bility of the tourism industry in the post-conflict areas of eastern Ukraine, taking into account the current features of their socio-economic development. The subject of the research: theoretical and practical aspects of increasing the profitability of tourism enterprises in Luhansk and Donetsk regions to restore the regional tourism industry and obtain a multiplier effect and the development of the socio-economic system of the region. The methods of the research: systems approach, structural-logical and statistical analysis, synthesis, generalization. The hypothesis of the research: involves the approach for tourism enterprises in the postconflict eastern territory of the country to review systematically and change outdated patterns of work to overcome the break-even point and the general systemic crisis after a long quarantine. The statement of basic materials. According to the results of the analysis, it is determined that for tourist enterprises of Luhansk and Donetsk regions are especially relevant: overcoming the negative impact of external factors, creating an innovative product and diversification of activities, integration into other industries. The main ways that will best help achieve the required level of profitability are digitalization and implementation of modern methods of personnel management, comprehensive marketing and advertising activities, as well as mandatory analysis of financial and economic performance. The originality and practical significance of the research: presented results and proposed recommendations are based on a comprehensive comparative analysis of the current situation of the tourism industry at the regional level, presented proposals are interested for practitioners and relevant for implementation in most tourism organizations in Donbass. Conclusions and prospects for further research. The main requirements for the success of the proposed areas getting rid of outdated patterns, validity and systematization in all processes and at all stages of work.

Key words:

tourism enterprise, profitability, economic efficiency, post-conflict territory, socio-economic development.

\section{ПРИБЫЛЬНОСТЬ ТУРИЗМА КАК ФАКТОР СОЦИАЛЬНО-ЭКОНОМИЧЕСКОГО РАЗВИТИЯ ПОСТКОНФЛИКТНОЙ ТЕРРИТОРИИ}

Постановка проблемы: Всемирная пандемия, вызванная COVID-19 привела к мировому кризису туристической отрасли, но в то же время создала условия для развития внутреннего туризма в Украине. Особенно, в этом шансе нуждаются постконфликтные территории Донбасса, где карантин усугубил депрессивную социально-экономическую ситуацию. Возникает вопрос поиска мер по восстановлению прибыльности субъектов туристической сферы данного региона. Цель исследования: определить направления повышения прибыльности туристической отрасли постконфликтных территорий востока Украины с учетом современных особенностей их социально-экономического развития. Предмет исследования: теоретические и практические аспекты повышения прибыльности туристических предприятий Луганской и Донецкой областей для восстановления работы региональной туристической отрасли и получения мультипликативного эффекта, а также развития социальноэкономической системы региона. Meтоды, использованные в исследовании: системный подход, структурно-логический и статистический анализ, синтез, обобщение. Гипотеза исследования: предусматривает использование подхода, согласно которому туристические предприятия постконфликтной территории востока страны должны системно посмотреть и изменить устаревшие шаблоны работы для преодоления точки безубыточности и общего системного кризиса после длительного карантина. Изложение основного материала. По результатам проведенного анализа установлено, что для туристических предприятий Луганщины и Донетчины особенно актуальны: преодоление негативного влияния внешних факторов, создание инновационного продукта и диверсификация деятельности, интеграция в другие отрасли. Основными способами, которые лучше всего помогут достижению необходимого уровня прибыльности, является диджитализация и внедрение современных методов управления персоналом, комплексные меры маркетинговой и рекламной деятельности, а также обязательный анализ полученных финансово-экономических показателей деятельности. Оригинальность и практическая значимость исследования: представленные результаты и предложенные рекомендации основываются на комплексном сравнительном анализе текущей ситуации туристической отрасли на региональном уровне, изложенные предложения представляют интерес для практиков и актуальные для внедрения в большинстве туристических организаций Донбасса. Bblводы. Главные требования успешности реализации предложенных направлений - избавление от устаревших шаблонов, обоснованность и системность во всех процессах и на всех этапах работы.

\section{Ключевые слова:}

туристическое предприятие, прибыльность, эффективность хозяйственной деятельности, посткнофликтная территория, социально-экономическое развитие. 
Постановка проблеми. Туристична індустрія - одна 3 галузей, яка є найбільш постраждалою внаслідок всесвітньої пандемії Covid-19. Кожна країна розробляє власний сценарій виходу з карантину, але вже зараз зрозуміло, що про високий літній сезон не йдеться, так як більшість держав залишають закритими власні кордони для іноземних відвідувачів. Україна не є виключенням: урядом країни запропоновано 5 етапів виходу 3 карантину [1], між попереднім і наступним етапами мінімальний інтервал складає 10 днів, але кожний регіон має свій режим послаблення карантинних заходів залежно від рівня захворюваності.

У будь-якому разі, цей літній туристичних сезон має стати випробуванням для кожної області України: не маючі можливості виїхати на відпочинок за кордон, вибагливі вітчизняні туристи шукають нові можливості відпочинку в межах регіону постійного проживання та на території інших областей. Пошук таких альтернатив відпочинку також обумовлений стрімким зниженням якості життя більшої частини населення внаслідок карантину. Скорочення або повна відсутнысть доходів протягом останніх декількох місяців, не дозволить більшості українців розглядати пропозиції іноземних провайдерів туристичних послуг з причини підвищення їх вартості. Це неминуче відбудеться, адже підвищуються витрати на додаткову сертифікацію місць розміщення для гарантування безпеки відвідувачів. Треба враховувати також нові витрати для отримання відповідних документів щодо підтвердження власне стану здоров'я самих туристів, які перетинають кордон [2].

В таких умовах всі регіони України отримали реальний шанс продемонструвати себе як привабливу туристичну дестинацію, принаймні для власного населення. 3 іншого боку, концентрація уваги на внутрішньому туризмі може відкрити приховані можливості регіонів щодо альтернативного шляху економічного розвитку. Прибутковість туристичної галузі на рівні кожної області - це пріоритет № 1, адже до початку пандемії дана індустрія демонструвала одні $з$ найвищих показників розвитку у світі, перетворювала депресивні регіони, на привабливі туристичні дестинації.

Великий шанс на розвиток внутрішнього туризму отримали і провайдери туристичних послуг східних регіонів України, зокрема
Луганська і Донецька області. Несприятлива епідеміологічна ситуація та неготовність більшості інших країн світу приймати українських туристів примушують місцеве населення шукати можливості для відпочинку в межах регіону постійного проживання. Враховуючи депресивність даних регіонів та сучасні несприятливі фактори розвитку в умовах геополітичного конфлікту, відновлення та розвиток внутрішнього туризму, 3 одного боку, відкриває можливості бюджетного відпочинку для власного населення; 3 іншого - це нові робочі місця, поповнення місцевих бюджетів за рахунок мультиплікативного ефекту туристичної індустрії.

Аналіз останніх досліджень та публікацій. Прибутковість туристичної галузі - це проблема, яку намагаються вирішити багато вітчизняних науковців та практиків. Серед дослідників на особливу увагу заслуговують роботи М. М. Нашкерської [3], О. О. Кузьменка [4], М. Г. Бойко [5], В. М. Шаповал, Т. В. Герасименко [6], Д. В. Нагернюк, Л. Г. Коваленко, В. О. Непочатенко [7] та інші.

Серед основних питань, яких торкаються зазначені та інші науковці висвітлюються:

1) поняття економічних інтересів туристичного підприємства [5, С. 48-49], а також економічна сутність, джерела, різновиди доходів і прибутків підприємства туристичної індустрії [4];

2) фактори та принципи підвищення економічної ефективності діяльності туристичних підприємств, серед яких вирішальним $\epsilon$ людський фактор - кваліфікована робоча сила $[6$, с. 83$]$;

3) технології формування прибутку підприємств в ринкових мовах, серед яких виділяють виробничу, фінансово економічну, інформаційно-правову та управлінську [7, с. 83];

4) особливості аналізу та оцінки фінансового стану результатів діяльності туристичного підприємства 3 використанням відповідних інструментів економікоматематичного аналізу [3, с. 170].

$\mathrm{He}$ зменшуючи вагомість результатів проведених досліджень, варто відзначити, що у більшості публікацій надано загальнотеоретичні рекомендації щодо підвищення прибутковості підприємств туристичної галузі. У той же час, незважаючи на наявні особливості, відсутні конкретні пропозиції, які б були розроблені для підвищення при- 
бутковості туристичних підприємств конкретного регіону. Більшість авторів, які торкаються окремих особливості функціонування галузі на регіональному рівні, приділяють увагу західним та південним областям, оминаючи решту регіони країни. Луганська і Донецька області взагалі поза увагою експертів.

Мета статті. Визначити напрями підвищення прибутковості туристичної галузі постконфліктних територій сходу України 3 урахуванням сучасних особливостей їх соціально-економічного розвитку.

Виклад основного матеріалу дослідження. Будь-яка підприємницька діяльність планується, створюється та відбувається 3 метою отримання прибутку. Умовами прибуткової діяльності туристичного підприємства $є$ наявність попиту на його послуги, конкурентоздатність продуктів, що пропонуються, платоспроможність потенційних клієнтів, тощо. Тільки наявність прибутку характеризує результативність господарської діяльності, створює можливість розподілу доходів суспільства між державою, підприємством та його персоналом, залишає турфірму на ринку послуг, дає поштовх до удосконалення та подальшого розвитку.

Підприємство певної галузі має загальні i специфічні джерела формування доходів, які, у свою чергу, є єдиною можливістю отримання прибутку. Предметом діяльності туристичного підприємства $є$ реалізація туристичної послуги, що має ряд особливостей у порівнянні 3 продуктами сфери обслуговування. Відповідно, є особливості і у способах отримання і доходу і прибутку.

Визнано, що прибутком э частина доходів, що залишається у розпорядженні підприємства після відшкодування всіх витрат на основну та іншу діяльність і сплати всіх обов'язкових платежів. Фірми туристичної галузі отримують доходи зі звичайної та надзвичайної діяльності. Звичайною діяльністю для даних підприємств $є$ реалізація стандартного або унікального туристичного продукту (як комплексного, так і окремих послуг) індивідуальним та груповим клієнтам. Додатково можна отримувати доходи від фінансової діяльності (дивіденди у вигляді отриманих процентів), інвестицій та інших операцій (реалізації майна та активів, участі в капіталі, доходи від курсових різниць тощо), торгівлі супутніми товарами. Серед інших звичайних доходів турфірма може мати доходи від безоплатно одержаних активів, от- риманих страхових та штрафних виплат. Крім того, можливе отримання доходів від надзвичайної діяльності, тобто такої, що не була запланована, а отриманий кошти не передбачалися взагалі. Зазвичай, це прибутки які виникають в результаті форс-мажорних подій [4].

Аналіз основних джерел формування доходів і прибутків підприємств туристичної галуз дозволяє зазначити, що для більшості турагентів постконфліктних територій сходу країни основним джерелом прибутку $є$ реалізація імпортованих туристичних продуктів та послуг, надання яких відбувається за межами країни. Набагато рідше це може бути національний туристичний продукт, шо пропонується провайдерами західних та південних областей. В результаті, за даними статистики, кількість туристів 3 Донбасу, що мандрували у межах країни у 2018 р. складала 5,6 тис. осіб, у той час як за межі країни для відпочинку виїхало 28,8 тис. осіб, тобто із загальної кількості обслужених туристів 3 Донбасу тільки 16\% обрали відпочинок в Україні, решта $84 \%$ виїжджали закордон. Цей факт підтверджую керівників провідних туристичних агенцій м. Сєвєродонецьк - сучасного обласного центру Луганської області. Загальна точка зору, яку висловили менеджери 3 туризму, - «реалізація стандартних закордонних пропозицій - це гарантовані «швидкі» гроші, так як наш турист користується сформованими стереотипами», але в умовах пандемії, коли закриті більшість кордонів, агенції втрачають значні прибутки, займаючись останні три місяці перенесенням турів та очікуючі коли відкриють свої кордони для українців закордоні туристичні дестинації. У той же час власники туристичних агенцій розповідають, що до них періодично звертаються потенційні клієнти із проханням організувати екскурсію у межах області для школярів або для колективів підприємств, запитують про тури вихідного дня без виїзду за межі регіону. Нажаль, більшість таких запитів залишаються без уваги.

Така однобічна політика формування туристичної пропозиції призвела до того, що у процесі зняття карантинних обмежень діяльність більшость туристичних агенції залишається «паралізованою», напрямки за якими вони працювали та відправляли туристів і досі закриті. Багато працівників туристичної галуз втратили свої робочі місця,

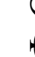


більшість 3 них так і не повернулися до роботи після послаблення карантинних заходів.

Про важливість відновлення регіонального туризму на постконфліктних територіях вже зазначалося у попередній публікації [12, с. 11] - це відновлення соціальноекономічних зв'язків постконфліктного регіону, створення нових робочих місць у багатьох суміжних галузях та за рахунок самозайнятості місцевого населення у сфері гостинності, широкі можливості для відновлення і розвитку культурних традицій, тощо. Відповідно, розпочинати роботу з відновлення туристичної сфери Донбасу потрібно вже зараз, змінюючи фокус діяльності для забезпечення економічної ефективності іiі функціонування:

- найбільш перспективним, на думку експертів, для цього сезону є оздоровчий та екологічний туризм із активним залученням автотранспортних перевезень $[10 ; 11]$; в умовах обмеженого залізничного сполучення саме на такий відпочинок в межах країни та власного регіону мають робити ставки туристичні агенції Луганської та Донецької області;

- переоріснтація 3 реальних подій на події у он-лайн середовищі [9], використовуючи мультибрендовість (пропозицію туристичних продуктів різних операторів, екскурсійних бюро та інших учасників ринку, i тому числі власних). Зокрема, для підтримки зацікавленості майбутніх відвідувачів, провідні екскурсоводи країни, об’єднавшись у соціальних мережах, протягом всього періоду карантину пропонують відвідати онлайн екскурсії відомими та невідомими містами, відкриваючи нові сторінки історії, культури, сучасності. Необхідно віддати належне 3МІ Луганської та Донецької області: цього року на регіональних каналах випущено цілий цикл програм про дивовижні куточки та цікаві місця Донбасу, які активно розповсюджуються серед користувачів соціальних мереж; нажаль у цей процес поки дуже мало залучені самі провайдери туристичних послуг;

- соціальна згуртованість та діалог між представниками туристичного бізнесу, громадою та органами влади на національному, регіональному та місцевому рівні: більшість представників туристичної індустрії, що $є$ представниками малого та середнього бізнесу, опинилися зараз у скрутному становищі через тривалий період карантину, тому дуже доречною є готовність держави та місцевих органів влади почути про проблеми підприємців, надати їм реальну інформаційну i фінансову підтримку. На цей пункт варто звернути увагу східним регіонам України. Судячи з інформаційних повідомлень, західні області, враховуючи, що туризм є однією 3 найбільших доходних статей місцевих бюджетів, вже зараз активно спільними зусиллями органів влади та представників туристичної галузі узгодили й впроваджують стратегію виходу індустрії з карантину, спираючись на інтереси малих підприємств та приватних підприємців. Інформація про результати спільної роботи щодо відновлення функціонування туристичних дестинацій західних областей майже щоденно поширюється у національних 3МI. Натомість, суб' єкти туристичної галузі постконфліктних територій сходу країни, натомість, намагаються виживати самотужки, розраховуючи тільки на власні ресурси.

Від загальних рекомендацій щодо організації роботи на цей туристичний сезон варто перейти до конкретних пропозицій із підвищення прибутковості діяльності на рівні кожного окремого туристичного підприємства, що функціонують на території Луганської та Донецької області (табл. 1).

Деякі пункти табл. 1 потребують додаткових пояснень:

1. Впровадження сучасних методів управління персоналом. Криза - найбільш сприятливий час для переналаштування, навчання, підвищення кваліфікації керівництва та персоналу, адже персонал в туристичному бізнесі - це основне джерело прибутку. Сьогодні існують перевірені часом та практикою рекомендації для удосконалення роботи 3 кадрами: якісний підбір персоналу, в якому перевагу потрібно віддати не досвідченому фахівцю, а новачку, який здатний навчатись та готовий працювати на результат; рекомендується тримати в офісі декілька менеджерів, а не одного-двох, що спонукає до здорової конкуренції; кожний працівник повинен отримувати певний запланований обсяг роботи і норми обслуговування клієнтів. Керівник (власник) фірми не повинен витрачати час на звичайну роботу менеджера, а направити свої зусилля на розвиток бізнесу. У такий спосіб, при докладанні певних зусиль, турфірма виходить 3 кризи 3 новими продуктами і новими вміннями, що робить іiі більш сильним гравцем ринку. 
Напрями підвищення прибутковості туристичних підприсмств Луганської та Донецької області

\begin{tabular}{|c|c|}
\hline Шляхи & Способи \\
\hline $\begin{array}{l}\text { Зменшення впливу негативних факторів: } \\
\text { сезонності, значного ступеня залежності від } \\
\text { транспортних підприєств, засобів розміщення, } \\
\text { харчування, екскурсійних послуг та інших роз- } \\
\text { ваг всіма можливими способами або ресурсами }\end{array}$ & \begin{tabular}{ll}
\multicolumn{1}{c}{ Діджиталізація діяльності: } \\
$-\quad$ & створення інтернет-офісу, чат-боту; \\
використання інтернет-можливостей для по- & шуку та опитування наявних або потенційних \\
клієнтів; \\
-
\end{tabular} \\
\hline \begin{tabular}{l} 
Диверсифікація - розширення асортименту \\
\multicolumn{1}{c}{ пропозицій: } \\
пошук та освоєння нових напрямків та видів \\
турів; \\
впровадження екскурсійної діяльності; \\
послуги з івент-туризму та анімаційної дія- \\
льності; \\
надання послуг івент-менеджменту; \\
комерційна рекламна діяльність
\end{tabular} & 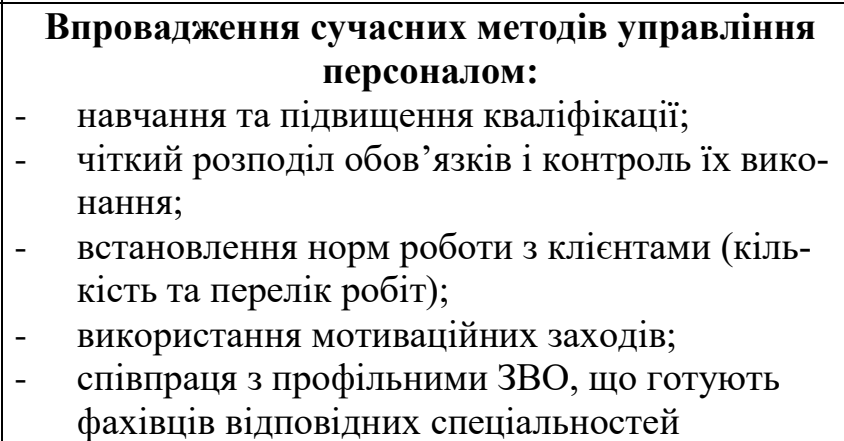 \\
\hline $\begin{array}{l}\text { Інтеграція з підприсмствами споріднених } \\
\text { галузей: } \\
\text { отримання довготривалої підтримки органів } \\
\text { місцевого самоврядування; } \\
\text { участь у створенні центрів сільського та ін- } \\
\text { ших видів екологічного туризму, археологі- } \\
\text { чних дослідженнях; } \\
\text { придбання або оренда засобів розміщення, } \\
\text { автобусів, туристичного обладнання тощо }\end{array}$ & $\begin{array}{l}\text { Комплексна маркетингова та повноцінна рек- } \\
\text { ламна кампанія } \\
-\quad \text { систематичне дослідження ринку; } \\
-\quad \text { за допомогою декількох найбільш доцільних } \\
\text { та ефективних рекламних інструментів (озна- } \\
\text { йомча, нагадувальна, інформаційна: про акції } \\
\text { та унікальні пропозиції); } \\
\text { - } \quad \text { виготовлення рекламної сувенірної продукції }\end{array}$ \\
\hline $\begin{array}{l}\quad \text { Створення інноваційних } \\
\quad \text { продуктів та послуг: } \\
\text { створення унікальних або індивідуальних } \\
\text { турів; } \\
\text { створення екскурсій різної тематичної спря- } \\
\text { мованості для будь-яких категорій туристів } \\
\text { (діти, іноземці, студенти, представники різ- } \\
\text { них професій або соціальних груп); } \\
\text { участь у соціально-відповідальних заходах } \\
\text { (проведення безкоштовних заходів, що ма- } \\
\text { ють краєзнавчий або патріотичний напря- } \\
\text { мок). }\end{array}$ & 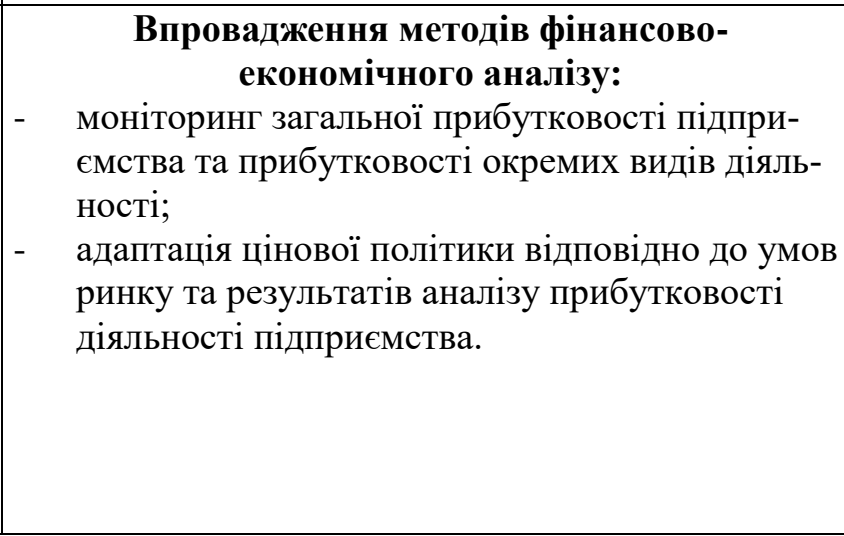 \\
\hline
\end{tabular}

\section{Джерело: розроблено авторами}

2. Соціально-відповідальна діяльність за межами власного підприсмства (безкоштовні послуги різних форм, участь у громадських проектах) вона набуває поваги та підтримки від органів місцевого самоврядування, населення регіону, але мало хто з власників туристичних підприємств Луганської та Донецької областей розуміє важливість такої роботи, вважаючи ці дії марнотратством власного часу.

3. Діджиталізація діяльності, зокрема, роботи $з$ клієнтами, що поділяються на нових та тих, що звертаються вдруге. В турфірмі повинна існувати клієнтська база, що систематизує нових клієнтів, серед яких повинні бути і ті, хто звернувся, але не придбав тур. Особливу увагу потрібно приділяти так званій конверсії, - повторному звертанню клієнтів. Але зазвичай туристичне підприємство мало звертає уваги на тих, від кого вже отримали прибуток. Серед потужних гравців на туристичному ринку існують навіть норми конверсії, наприклад, у клієнтів «з вулиці» близько $35 \%$, з сайту - $20 \%$, постійні клієнти - 
$60 \%$ і т.д. В останні роки широко застосовуються у туристичних офісах CRM-системи, які автоматизують велику частину роботи 3 клієнтами, а саме вибудовують ланцюжок та графік роботи 3 клієнтами (дзвінки 3 нагадуваннями, розсилка, привітання зі святами, повідомлення про акції та інші цікаві пропозиції тощо). Витрати на придбання такого програмного продукту є немалими, але цілком виправданими у подальшій роботі підприємства.

4. Комплексна маркетингова та рекламна діяльність туристичного підприємства також надзвичайно важлива для досягнення бажаних обсягів продажів, та, відповідно, рівня прибутку. Обов'язково, кожна фірма повинна дослідити свій потенційний ринок зі всіма його особливостями (регіональними, економічними, демографічними тощо) та конкурентами. Існуе спірна, але цікава думка про створення портрету цільового клієнта, під який потім зручно вибудовувати правильні маркетингові та рекламні активності. Не менш важливим $\epsilon$ соціальний маркетинг: включення в рекламні продукти інформації про соціальні заходи підприємства значно підвищить рівень довіри до самої фірми та іiї продуктів.

5. Впровадження методів фінансовоекономічного аналізу. Для досягнення впевненої ринкової позиції потрібно відпрацювати та постійно тримати на контролі цінову політику продажів. Неможна дотримуватись політики тільки дешевих турів та послуг, які, відповідно, мають низьку рентабельність. Демпінг допустимий за наявності значної фінансової стійкості. Обов'язково, $з$ певною періодичністю необхідно проводити аналіз отриманих фінансових результатів 3 визначенням факторів та обставин, що призвели до отриманого результату для коригування своєї майбутньої діяльності. Необхідно зазначити, що на території Донбасу також мають бути пропозиції для VIPклієнтів, але цінова політика таких пропозицій має бути збалансована відповідно до умов пропонованого туристичного продукту.

6. Інтеграція 3 підприємствами споріднених галузей. Характерна риса успішного та прибуткового бізнесу - постійний пошук і розвиток. Такі дії повинні бути як в бік інтеграції (об'єднання або зміцнення зв'язків зі спорідненими галузями), так i в сторону диверсифікації - створення радикально нових продуктів свого напрямку (нові тури та екскурсії), так і інших, наприклад, надання інформаційних, консалтингових, рекламних послуг.

Висновки та перспективи подальших досліджень. На підставі проведених досліджень, можна підсумувати наступне:
1) прибутковість - необхідна умова існування та розвитку підприємств будь-якої, у тому числі туристичної галузі. Отримання бажаного рівня прибутковості - результат комплексної ефективної роботи за декількома напрямами, які напряму можуть бути i не пов'язані з економічними процесами, але опосередковано впливають на їх якість та успішність;

2) вітчизняний туристичний бізнес заради свого виживання на фоні всесвітньої пандемії та отримання перспектив подальшого розвитку, має скорегувати свою діяльність у різних напрямках. Для туристичних підприємств Луганщини і Донеччини особливо актуальні: подолання негативного впливу зовнішніх факторів, створення інноваційного продукту та диверсифікація діяльності, інтеграція в інші галузі. Основними способами, що найкраще допоможуть досягненню необхідного рівня прибутковості, є діджиталізація та впровадження сучасних методів управління персоналом, комплексні заходи маркетингової та рекламної діяльності й обов'язковий аналіз отриманих фінансово-економічних показників діяльності. Головні вимоги успішності - позбавлення від застарілих шаблонів роботи, обгрунтованість та системність у всіх процесах і заходах.

Втручання у світовий бізнес пандемії Covid-19 змусило турфірми шукати шляхи виходу 3 кризи і у стані шоку опановувати нові форми роботи. Цей вплив 3 великою ймовірністю міг бути не від пандемії, а від будь-якої іншої раптової зовнішньої загрози, тому наданий урок обов'язково повинен бути засвоєний. Цьогорічна ситуація та закриті кордони надають величезний шанс туристичній галузі Донбасу показати себе у «новому світлі», привернувши увагу власного населення до невідомих але вартих уваги туристичних атракцій.

\section{Література}

1. Прем'єр-міністр Денис Шмигаль представив поетапний план зняття обмежень. Урядовий портал. 2020. 24 квітня. URL: https://www.kmu.gov.ua/news/premyer-ministrdenis-shmigal-predstaviv-poetapnij-plan-znyattyaobmezhen (дата звернення: 14.05.2020 p.)

2. Отпуск в условиях COVID-19. Как теперь будет выглядеть туризм в разных странах. Рубрика. 2020. 2 мая. URL: https://rubryka.com/ru/article/turyzm-na-karantyni/ (дата звернення: 11.05.2020 p.)

3. Нашкерська M. М. Особливості аналізу фінансового стану і результатів діяльності туристичного підприємства. Соціально- 
економічні проблеми сучасного періоду України. Вип. 5 (133). 2018. С. 169-173.

4. Кузьменко О. О. Особливості формування та класифікація доходів туристичного підприємства. Економіка. Управління. Інновації. Серія: Економічні науки. 2016. Вип. 3 (18).

5. Бойко М. Г. Методичні основи оцінювання економічних інтересів туристичних підприємств. Економічний часопис XXI. 2012. № 9-10. C. 24-34.

6. Шаповал В. М., Герасименко Т. В. Фактори та принципи підвищення ефективності діяльності підприємств туристичної галузі. Економічний вісник. 2016. № 3. С. 79-85.

7. Нагернюк Д. В., Коваленко Л. Г., Непочатенко В. О. Основні аспекти прибутковості туристичних підприємств. Економіка та суспільство. 2018. Вип. 17. С. 300-307.

8. Офіційний вебсайт Головного управління статистики у Луганській області: URL: http://lg.ukrstat.gov.ua (дата звернення: 14.05.2020 p.)

9. Офіційний вебсайт Головного управління статистики у Донецькій області: URL: http://donetskstat.gov.ua (дата звернення: 14.06.2020 p.)

10. Туризм в умовах пандемії COVID-19: як європейці проведуть це літо? DW: Made for Minds. 2020. 17 квітня. URL: https://www.dw.com/uk/туризм-в-умовах-пандеміï (дата звернення: 12.05.2020 p.)

11.Втрати і шанси. Чи залишиться Львів туристичним містом? Твос місто. 2020. Квітень. URL: http://tvoemisto.tv//vtraty_shansy_ chy_zalyshytsya_lviv_turystychnym_mistom_108 364.html (дата звернення: 10.05.2020 p.)

12.Зеленко О. О. Економічно-соціальні передумови розвитку постконфліктної території засобами туризму. Часопис економічних реформ. 2019. № 4 (36). С. 6-12.

\section{Reference}

1. Prime Minister Denis Shmygal presented a phased plan to lift restrictions. Government portal. 2020. $24^{\text {th }}$ of April. Retrieved from: https://www.kmu.gov.ua/news/premyer-ministr-

Стаття надійшла

до редакції : 15.05 .2020 p. denis-shmigal-predstaviv-poetapnij-plan-znyattyaobmezhen

2. Vacation in the conditions of COVID-19. What will tourism in different countries look like now? Heading. 2020. $2^{\text {nd }}$ of May. Retrieved from: https://rubryka.com/ru/article/turyzm-na-karantyni/

3. Nashkerskaya, M. M. (2018). Features of the analysis of a financial condition and results of activity of the tourist enterprise. Socio-economic problems of the modern period of Ukraine, 5 (133), 169-173.

4. Kuzmenko, O. O. (2016). Features of formation and classification of incomes of the tourist enterprise. Economy. Management. Innovations. Series: Economic Sciences, 3 (18).

5. Boyko, M. G. (2012). Methodical bases of estimation of economic interests of tourist enterprises. Economic Journal XXI, 9-10, 24-34.

6. Shapoval, V. M., Gerasimenko, T. V. (2016). Factors and principles of improving the efficiency of the tourism industry. Economic Bulletin. № 3. pp. 79-85.

7. Nagernyuk, D. V., Kovalenko, L. G., Nepochatenko, V. O. (2018). The main aspects of profitability of tourism enterprises. Economy and society, 17, 300-307.

8. Main Department of Statistics in Luhansk Oblast: official website. Retrieved from: http://lg.ukrstat.gov.ua

9. Main Department of Statistics in Donetsk Oblast: official website. Retrieved from: http://donetskstat.gov.ua

10.Tourism in the context of the COVID-19 pandemic: how will Europeans spend this summer? DW: Made for Minds. 2020. $17^{\text {th }}$ of April. Retrieved from: https://www.dw.com/en/tourism-inthe-pandemic-covid-19

11.Losses and chances. Will Lviv remain a tourist city? Your city. 2020. April. Retrieved from: http://tvoemisto.tv/exclusive/vtraty_i_shansy_chy_ zalyshytsya_turystychnym_mistom_108364.html

12.Zelenko, O. O. (2019). Economic and social preconditions for the development of the postconflict territory by tourism means. Time Description of Economic Reforms, 4 (36), 6-12.

Стаття прийнята

до друку: 26.06.2020 p.

Бібліографічний опис для цитування :

Зеленко О. О. Прибутковість туристичної галузі як фактор соціально-економічного розвитку постконфліктної території / О. О. Зеленко, Л. В. Денищенко // Часопис економічних реформ. - 2020. - № 2 (86). - C. 14-21. 